\title{
The Price of Team Spirit for Sensemaking through Task Discourse in Innovation Teams
}

\author{
Martin Ratzmann, Robin Pesch, Ricarda Bouncken, Carla Martínez Climent
}

\begin{abstract}
Despite interest in innovation teams, we have only limited insights into how team members make sense of innovation teams' inherent ambiguity. By referring to the sensemaking literature and to the research on task discourse, this study introduces task discourse as a valuable sensemaking mechanism in innovation teams. We argue that team creativity and feasibility testing increase the need for task discourse, which, in turn, improves team performance. We further consider ambivalent effects of team spirit. On one hand, through team spirit synergies emerge, but on the other, high team spirit can limit team members' willingness to challenge each other's different perspectives and opinions. Data from 250 innovation teams at German manufacturing firms support the assumed beneficial effects of task discourse and the ambivalent effect of team spirit. Our results indicate that teams need sensemaking through task discourse when they want to achieve benefits from team creativity. Our study enriches current research on ambiguity and sensemaking in innovation teams, answers the call to elaborate advantages and disadvantages team spirit might bring to teams, and provides valuable managerial implications.
\end{abstract}

Keywords Sensemaking. Task discourse $\cdot$ Ambiguity $\cdot$ Team spirit $\cdot$ Innovation team 


\section{Introduction}

Innovation teams face a dilemma. Team members' different functional backgrounds provide the potential for complementary perspectives and problem-solving approaches (Bain et al. 2001), and the innovation teams' inherent diversity creates opportunities for learning and makes finding novel solutions more likely (Bouncken et al. 2016a; Williams and O'Reilly 1998). However, team members' different expectations for teamwork and divergent ways of thinking fuel task and interactional ambiguity, which can escalate into dysfunctional conflicts (van Knippenberg and Schippers 2007). As a consequence, team failures are numerous, such as budget and schedule overruns, missed opportunities, and team collapse (Pich et al. 2002). Interactional tensions impede the realization of innovation teams' inherent creativity and problem-solving potential (Hoegl and Gemuenden 2001). Therefore, innovation teams need to make sense of ambiguities to integrate team members' different perspectives and problemsolving approaches.

Our model introduces task discourse as a means for innovation teams to make sense of ambiguities. Task discourse relates to the open and constructive discussion of task understanding, task completion, and problem-solving approaches for the development of shared understanding (Pesch and Bouncken 2017a). The theoretic lens of this our study is the literature on sensemaking (Akgün et al. 2012; Maitlis and Christianson 2014; Weick 1995) and discourse (Pesch and Bouncken 2017b). The model hypothesizes that team creativity and feasibility testing can trigger sensemaking through task discourse, which, in turn, can increase team performance. We further consider the role of team spirit, because socio-cognitive factors shape team functioning (Akgün et al. 2006). Team spirit as the feeling of a sense of group togetherness (Silva et al. 2014) facilitates team functioning (Cabrales and Calvó-Armengol 2007; Hackman 2012) and might advance sensemaking. However, team spirit is a double-edged sword for team decision-making processes. On one hand, through team spirit synergies emerges (Boyt et al. 2005). On the other, high team spirit can limit team members' willingness to challenge each other's different perspectives and opinions.

To test the hypothesized model, we use structural equation modeling on survey data from 250 innovation teams. Each team provided data from two team members. The results mainly support the hypothesized model. By introducing task discourse as a sensemaking mechanism in the team context, we enrich the research on team sensemaking (Akgün et al. 2012; Brun 2016). We further relate to research on socioemotional processes (Stewart and Barrick 2000), as we elaborate the interplay between task discourse and team spirit in innovation teams and follow the call to consider positive and negative effects of team spirit (Silva et al. 2014). The ambivalent effects of team spirit further contribute to research on dissent avoidance in teams (Janis 1972). Our study also provides managerial implications.

\section{Theoretic Framework and Hypotheses}

\subsection{Task Discourse as Means to Make Sense in Innovation Teams}


Innovation teams are organizational workgroups in which individuals from diverse functional backgrounds work together for a limited time to create, develop, and implement innovation (Akgün et al. 2006). Team researchers (Burningham and West 1995; Hoegl and Gemuenden 2001) and creativity scholars (Amabile 1996) have provided evidence in various study settings that teams increase innovation. Teams can pool diverse resources, especially knowledge and perspectives that may breed novel ideas or improvements of previous solutions (Im et al. 2013; Kratzer et al. 2004; Miron-Spektor et al. 2011). Innovation teams process information by encoding, storing, and retrieving it (Leenders et al. 2007). Although teams can help to reduce the inherent uncertainty of innovation processes (Aç1kgöz et al. 2016), teams do not always make good use of their informational resources as the teams often fail to recognize opportunities and combine members' unique knowledge (Angelsberger et al. 2017; Stasser 1999; Wittenbaum and Stasser 1996). Team members may feel overwhelmed by ambiguity (Wright et al. 2000). Ambiguity describes different interpretations of the same cue (Brun 2016). These different interpretations emerge from team members' different knowledge, behaviors, cognitions, and functional cultures. Different functional backgrounds and cultures are similar to different "thought worlds," each with a specific focus on the task and making different sense of the total (Dougherty 1992). Although these differences can extend problem-solving potential and thus, improve decision quality, these differences are likely to cause ambiguity and conflicts (Camelo-Ordaz et al. 2015; Pesch et al. 2015; van Knippenberg and Schippers 2007). Innovation tasks are also often complex, risky, and timepressured enhancing ambiguity and uncertainty (Bouncken and Kraus 2013; Leenders et al. 2007). Ambiguity about tasks, how things should be done, and how one should behave within a team creates faultlines and might fuel escalating conflicts (Li and Hambrick 2005). Different media applications in virtual team contexts (e.g., telephone and e-mail) can overcome geographic and temporal dispersion of organizational members but may also increase interactional ambiguities (Sivunen 2006; Slevin et al. 1998; Workman et al. 2003).

Ambiguities can also be a source of constructive conflicts, rich understanding, knowledge creation and innovation opportunities (Bouncken et al. 2016b; Giordano et al. 2017). Teams can realize this extended problem-solving potential, when team members are able to externalize and to integrate their different thoughts to solve current problems or to generate new knowledge (Oppl 2017). Thus, teamwork requires mechanisms that enable team members to cope with ambiguity and to integrate their different thought worlds to create innovative solutions.

Lovelace et al. (2001) show that cross-functional teams need communication pluralism. Specifically, sensemaking processes draw upon differences and construct meaning (Weick 1995). Sensemaking is a social process (Christiansen and Varnes 2009) as it relates to the interaction of individuals, who attempt to explain and understand a novel, unclear, or confusing event by applying language, talk, and communication (Weick 2005). Team research has pointed out the importance of sensemaking for teams' operations and performance because team members cannot use their different knowledge unless they begin making shared sense of each other's expertise (Dougherty et al. 2000). Sensemaking is strongly 
related to discourse through which individuals construct meaning (Phillips et al. 2004). In innovation teams, task discourse acts as a crucial sensemaking mechanism. Task discourse relates to constructive discussions about task understandings and about how tasks should be performed (Pesch and Bouncken 2017a). Task discourse occurs when innovation team members share, question, and challenge each other's various perspectives and task-completion methods (Pesch and Bouncken 2017a; Tsai and Bendersky 2016). Discourse includes cognitive processes of information sharing and motivational processes of interaction (De Dreu and Gelfand 2008). Open and constructive discourse helps team members detect the limitations of their personal views and create insights into complementarities (Tjosvold et al. 2014). Task discourse in innovation teams improves knowledge implementation and leads to early detection and correction of problems and errors during the innovation process. Discussing each other's perspectives enables team members to interpret the technology-, market- and team-related information (Akgün et al. 2012; Wright et al. 2000). Task discourse supports the development of shared understanding with which team members can collectively respond to market-, technology-, and productrelated events. Based on mutual insights gleaned through task discourse, team members construct a more comprehensive understanding of reality. Task discourse challenges conventional thinking and identifies opportunities and threats (Pesch and Bouncken 2017b). Teams require discourse to make sense while they also offer a platform for discourse (Ashmos and Nathan 2002). Summarizing, discourse about each other's ideas and task completion methods support team members to overcome ambiguity leveraging the inherent merits of teamwork.

H1 Task discourse increases an innovation team's performance.

\subsection{Team Creativity and Task Discourse}

Sensemaking enables team members to clarify ambiguous situations while ambiguity itself also stimulates sensemaking (Weick 1995). Creative work in innovation teams is a common source of ambiguity. Team creativity relates to team members' development of novel ideas and solutions that progress a firm's competitive advantages (Amabile 1996; Barczak et al. 2010; Elsbach and Hargadon 2006). However, team creativity is demanding (Brun 2016), as it involves the combination and integration of various inputs and knowledge from multiple and interdependent team members (Chen 2006). Developing creative ideas sources ambiguities and stimulates task discourse through which team members try to understand each other's ideas and competencies. Ideas alone are not sufficient for innovations (Bouncken et al. 2016a). Often, novel ideas fail because they do not align with organizational processes or business models. Thus, team members need to clarify whether more effort spent on the realization of a specific creative idea will pay off. To evaluate the potential of novel ideas, team members can enter a discourse about creative ideas. Task discourse enables team members to reflect and challenge their assumptions underlying novel ideas. Furthermore, discourse about how the idea fits organizational processes and a firm's business model helps to avoid failure. Task discourse can lead to adoption and refinement of creative ideas. Consequently, we argue that the greater the team's 
creativity, the greater the need for and the likelihood of task discourse, as individuals tend to overcome perceived ambiguities driven by creative work.

H2 The greater the team's creativity, the greater the task discourse.

\subsection{Feasibility Testing and Task Discourse}

Innovation teams need to be creative during all stages of the innovation project. Creative solutions have to work. Thus, teams have to test whether their solutions are feasible. Firms have established formal testing procedures and apply performance measures especially when the firms follow a stage-gate process for their innovation projects (Calantone et al. 1988). In a stage-gate process, firms define performance measures and gates (Cooper et al. 1999). Although the performance measures and gates are clear, the technical or market setup for testing can focus on diverse performance criteria and differ. Team members from different functional and knowledge domains have different ideas and preferences for procedure or evaluation criteria. These different evaluation criteria clash during teamwork and need to be clarified through discourse. Task discourse can help to synchronize different feasibility criteria among different units in the firm. Beyond this, feasibility testing is normally an iterative trial-and-error process. During this process, questions can arise and unexpected problems can occur that require reflection, coordination, and synchronization. Therefore, feasibility testing breeds task discourse that enables team members to understand the deviations from their expectations and to initiate required adaptions. Team members participate in the discourse to challenge their assumptions and past actions (Pesch and Bouncken 2017a). Consequently, we argue that as the level of feasibility testing increases in a team, the more likely task discourse will occur among team members.

H3 The greater the feasibility testing, the greater the task discourse.

\subsection{Team Spirit}

The socio-cognitive perspective of teams (Akgün et al. 2006) highlights contextual factors for understanding complex team processes, such as task discourse. Team spirit as "esprit de corps" is an important team factor (Jaworski and Kohli 1993; Salojärvi and Saarenketo 2013) that can have ambivalent effects on teams (Silva et al. 2014). Team spirit describes the feeling of a sense of group togetherness (Silva et al. 2014) and. Team spirit is the degree of how obligated team members feel by common goals and to each other (Boyt et al. 2005). This "we" feeling is associated with team members' loyalty, enthusiasm, and devotion to the group manifested in team members' commitment to achieve common goals (Boyt et al. 2005). Although previous research highlights team spirit as an important concept for team functioning (Cabrales and Calvó-Armengol 2007; Hackman 2012), scholars typically assume this concept is present rather than to explore it as a research topic per se (Silva et al. 2014). Team spirit reflects team members' willingness to pull together and regard the completion of a task as a shared responsibility regardless of functional borders (Salojärvi and Saarenketo 2013). Helping behavior 
among team members is also associated with team spirit, improving teams' efficiency and effectiveness in fulfilling tasks (Boyt et al. 2005).

H4 Team spirit increases an innovation team's performance.

Although team spirit can encourage team members to exchange information altruistically (Smith et al. 2009), team spirit can limit the beneficial effects that task discourse has on team performance. Several studies have shown that contextual factors affect the information sampling and sharing for decisionmaking (Wittenbaum 1998; Wittenbaum et al. 2004). The hidden profile paradigm (Stasser 1992; Stasser and Titus 1985) examines whether and why task-relevant individual information is introduced to the group. Postmes et al. (2001) showed that groups have critical evaluation norms. Groups with highly developed critical evaluation norms are more likely to solve a hidden profile correctly and value unshared information positively compared to groups with a consensus norm. Team spirit can foster consensus thinking and intensify dilemmas of the elephant in the room when critical aspects and information are unspoken or suppressed because they are in contrast to the (ostensible) consensus (Janis 1972). Team spirit can become oppressive and limit individual voice (e.g., groupthink) and the capability to live with (rather than to suppress) contradiction and paradox (Bollen and Hoyle 1990). Team members are more likely to reach consensus on decisions quickly and tend to defend decisions rather than find new alternatives (Mohammed and Ringseis 2001). However, task discourse lives from critically challenging each other's position and the integration of different views (Pesch and Bouncken 2017b). Thus, we assume that team spirit limits the positive effect of task discourse.

H5 Team spirit negatively moderates the relationship between team discourse and an innovation team's performance.

Fig 1 summarizes the hypothesized model.

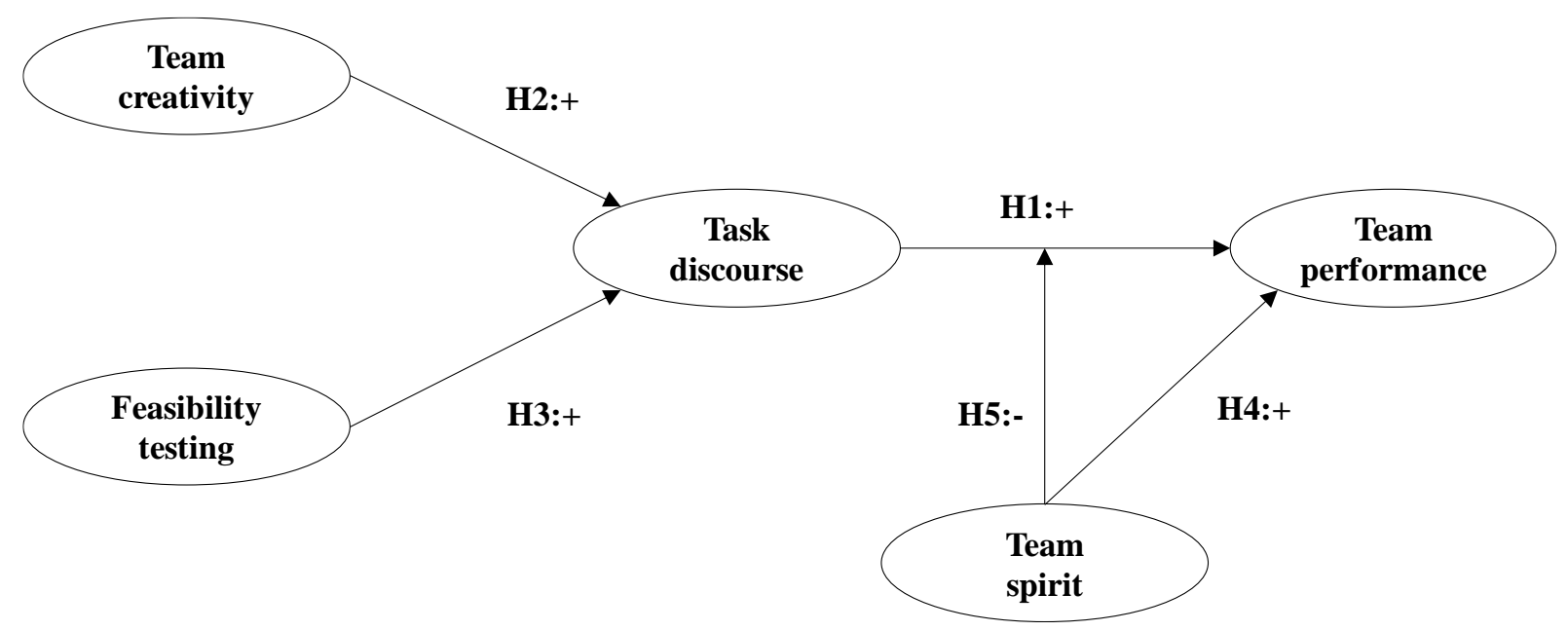

Fig 1: Framework and hypotheses 


\section{Method}

\subsection{Data Collection and Sample}

Our study draws on a survey of 250 innovation teams of German manufacturing firms. The manufacturing industry is with a share of $26 \%$ the most important industry in Germany (Statistisches Bundesamt 2014), a highly innovative industry and a research object of great interest (Habermann and Schulte 2017). Digital transformation has caused high innovation pressures but also unlocked new value potential through new types of business models and efficiency advantages in the manufacturing industry (Baarup et al. 2015).

Survey respondents were selected with the Amadeus database. We selected 1858 manufacturing firms for which Amadeus provides information about firm's revenues, return, and number of employees. We contacted all the firms via telephone to request they participate in the study. Two hundred ninety firms participated, representing a response rate of $15.6 \%$. Each firm provided two respondents: a team leader and a team member. Team leaders evaluated team performance, and team members responded to questions about team characteristics and processes (team creativity, feasibility testing, task discourse, and team spirit). Respondents in each firm referred to one innovation team with which they involved and which was completed within the last year. We omitted 40 questionnaires due to missing values. The firms in the sample have following characteristics: The average previous year's sales volume of the sample firms was about 130 million euro (median: 47 million euro), achieved with an average of 439 employees (median: 191 employees). The team size ranged from two to nine members with a mean of 4.56 and a standard deviation of 1.60. Eighty-eight percent of the team members were male. Team members' age ranged from 19 to 71 years with a mean of 42.22 and a standard deviation of 9.39. The team leaders had different functional positions $(43.6 \%$ were project managers, $38.0 \% \mathrm{R} \& \mathrm{D}$ directors, $8.4 \%$ construction directors, $4.4 \%$ production directors, $2.4 \%$ quality assurance director, and $2.4 \%$ director of the firms. The second respondents came from different areas, such as R\&D (mostly engineers, designers, and technical draftsmen), laboratory (chemists and programmers), and sales.

\subsection{Measurement Model and Parameter Estimation}

The study measured team creativity, feasibility testing, task discourse, team spirit, and team performance as latent variables operationalized on five-point Likert-type scales (see Table 1).

\subsubsection{Team Creativity}

To measure team creativity, we adapted three items from Jia et al.'s (2014) scale. These items capture team members' introduction, suggestions, and launching of creative ideas.

\subsubsection{Feasibility Testing}

Using Ziegler et al. (2000) and Girotra et al. (2010), we measured feasibility testing as the extent to which team members test and refine proposed ideas for implementation. 


\subsubsection{Task Discourse}

We adapted Pesch and Bouncken's (2017b) three-item scale to the team context to measure task discourse. These items refer to the openness and regularity with which team members discuss divergent opinions, ideas, processes, and procedures.

\subsubsection{Team Spirit}

Based on Silva et al.'s (2014) explanation of team spirit, the team spirit scale included three items about the responsibility for common goals, team cohesiveness, and balanced effort of team members.

\subsubsection{Team Performance}

The team performance measure consisted of three items that captured the achievement of schedule, of project objectives, and of the overall success (Hoegl and Gemuenden 2001).

\subsubsection{Validation}

We conducted a confirmatory factor analysis (CFA) to validate the measurement model and carefully examined convergent and discriminant validity based on the CFA results. To assess the fit of the measurement model, we follow $\mathrm{Hu}$ and Bentler (1999) and provided several fit indices from the confirmatory factor analyses: The chi-square divided by the degrees of freedom was 1.73 , the comparative fit index (CFI) was 0.97, the root mean square error of approximation (RMSEA) was 0.05, and the standardized root mean square residual (SRMR) was 0.05. Hair et al. (2010) suggest assessing the indicator loadings, the average variance extracted (AVE), and the composite reliability (CR) to test construct validity. Bagozzi and Yi (1988) recommend that factor loadings of indicators should be greater than 0.60 . Due to the limitations of Cronbach's alpha, we applied composite reliability to test reliability (Cho and Kim 2015). Composite reliability is adequate with values greater than 0.7 (Bacon et al. 1995). An AVE greater than 0.5 indicates appropriate extracted variance (Fornell and Larcker 1981; Olugbola 2017). With one exception, all standardized loadings are greater than $0.6, \mathrm{CR}$ is greater than 0.7 , and the AVE of the constructs exceeds 0.5 indicating adequate construct validity (see Table 1 ). We applied the Fornell-Larcker ratio to assess discriminant validity. Discriminant validity is the conceptual distinctiveness of measurement models. The Fornell-Larcker ratio indicates discriminant validity when a construct's AVE is greater than the square of its largest correlation with any construct (Fornell and Larcker 1981).

\subsubsection{Control Variables}

To isolate the effect of the predictor variables, we considered several relevant control variables. Previous research has shown that team performance depends on team size (Guzzo and Shea 1992). To control for this effect, we considered team size as the number of team members as an additional control variable. 
We controlled for a firm's R\&D intensity (R\&D investments/sales), as greater R\&D intensity might shape the performance of innovation teams. Because the task decides the composition of the team, related processes, and outcomes (Hackman and Morris 1983), we added control variables for innovation task type and novelty. We asked for information about product innovation versus process innovation regarding task type and for radical versus incremental regarding the novelty degree of the innovation developed in the team.

Table 1 Model-fit indices from Confirmatory Factor Analysis (CFA) ${ }^{\text {i, ii }}$

\begin{tabular}{|c|c|c|c|c|c|}
\hline Construct & Indicators & FL & $\mathbf{C R}$ & AVE & FLR \\
\hline \multirow{3}{*}{ Creativity } & The team members introduced creative ideas. & 0.92 & 0.84 & 0.64 & 0.42 \\
\hline & $\begin{array}{l}\text { The team members suggested that new paths } \\
\text { would be taken. }\end{array}$ & 0.85 & & & \\
\hline & $\begin{array}{l}\text { The team members launched a search for new } \\
\text { solutions. }\end{array}$ & 0.59 & & & \\
\hline \multirow[t]{3}{*}{ Feasibility } & $\begin{array}{l}\text { The team members tested the technical } \\
\text { feasibility of the ideas. }\end{array}$ & 0.82 & 0.89 & 0.73 & 0.34 \\
\hline & $\begin{array}{l}\text { The team members tested various } \\
\text { implementation methods. }\end{array}$ & 0.95 & & & \\
\hline & $\begin{array}{l}\text { The team members experimented until a } \\
\text { solution was reached. }\end{array}$ & 0.80 & & & \\
\hline \multirow[t]{3}{*}{ Task discourse } & $\begin{array}{l}\text { The team members communicated project- } \\
\text { relevant ideas and information openly. }\end{array}$ & 0.70 & 0.78 & 0.55 & 0.82 \\
\hline & $\begin{array}{l}\text { The team members were able to solve } \\
\text { discussions and disagreements constructively. }\end{array}$ & 0.73 & & & \\
\hline & $\begin{array}{l}\text { The team members recognized the different } \\
\text { ideas and opinions. }\end{array}$ & 0.80 & & & \\
\hline \multirow[t]{3}{*}{ Team spirit } & $\begin{array}{l}\text { Each team member felt fully responsible for } \\
\text { common goals. }\end{array}$ & 0.69 & 0.76 & 0.52 & 0.86 \\
\hline & The cohesion of the team was strong. & 0.72 & & & \\
\hline & $\begin{array}{l}\text { All team members contributed fully to the team } \\
\text { workload. }\end{array}$ & 0.76 & & & \\
\hline \multirow{3}{*}{$\begin{array}{l}\text { Team } \\
\text { performance }\end{array}$} & The project schedule was consistently achieved. & 0.82 & 0.94 & 0.83 & 0.26 \\
\hline & All project objectives were achieved. & 0.94 & & & \\
\hline & $\begin{array}{l}\text { Overall, the project can be regarded as } \\
\text { successful. }\end{array}$ & 0.97 & & & \\
\hline
\end{tabular}

\section{RESULTS}

We used the covariance-based structural equation modeling (SEM) approach with the software Mplus version 8 (Muthén and Muthén 1998-2012). Table 2 shows the correlations between the control and the exogenous and endogenous latent variables. 
Table 2 Correlations i, ii

\begin{tabular}{lccccccccc}
\hline & 1 & 2 & 3 & 4 & 5 & 6 & 7 & 8 & 9 \\
\hline 1 R\&D intensity & 1.00 & & & & & & & \\
2 Task type & $-0.09 *$ & 1.00 & & & & & & & \\
3 Task novelty & 0.04 & 0.03 & 1.00 & & & & & & \\
4 Team size & 0.03 & 0.09 & $0.11^{*}$ & 1.00 & & & & & \\
5 Team creativity & 0.02 & 0.09 & 0.04 & -0.02 & 1.00 & & & & \\
6 Feasibility testing & 0.04 & -0.05 & -0.01 & 0.09 & $0.53 * * *$ & 1.00 & & & \\
7 Task discourse & -0.06 & $0.14 * *$ & 0.12 & -0.11 & $0.33^{* * *}$ & $0.20^{* * *}$ & 1.00 & & \\
8 Team spirit & -0.00 & $0.12 *$ & $0.24 * * *$ & $-0.14 * *$ & $0.25 * * *$ & $0.18^{* *}$ & $0.67 * * *$ & 1.00 & \\
9 Team performance -0.04 & 0.07 & -0.04 & 0.07 & 0.07 & $0.17 * *$ & $0.47 * * *$ & $0.36 * * *$ & 1.00 \\
\hline
\end{tabular}

${ }^{\mathrm{i}} \mathrm{N}=250$

ii $* \mathrm{p}<.10, * * \mathrm{p}<.05$ and $* * * \mathrm{p}<.01$

Three models provide information about the testing of the hypotheses. The first model includes only the controls, the second model adds the latent variables of interest, and the third model includes the interaction of the latent variables estimated with Klein and Moosbrugger (2000) latent moderated structural (LMS) equation approach. The goodness-of-fit indices for all structural models indicated a good fit $\left(\chi^{2} / \mathrm{df} \leq 2.0\right.$; CFI $\geq 0.95 ;$ RMSEA $\leq 0.06$; SRMR $\leq 0.08$ ). In model 1 (only control variables), all control effects are insignificant. However, team size has a significantly positive $(\beta=0.15, p<0.05)$ and task novelty has a significantly negative $(\beta=-0.12, p<0.1)$ association with team performance in model 2 and model 3, respectively (see Table 3). Because these relationships become significance with the addition of the model variables, we investigate with a post hoc analysis of two three-way interaction effects between task novelty or team size with task discourse and team spirit on team performance. We discuss the three-way interaction effects in the discussion section. Model 2 reaches an $\mathrm{R}^{2}$ for team performance of 0.28 with a $p$ value of less than 0.01 . Model 2 shows a significantly positive association between task discourse and team performance $(\beta=0.34, p<0.01)$, supporting hypothesis 1 . The association between team creativity and task discourse is significantly positive $(\beta=0.31, p<0.01)$; thus, $\mathrm{H} 2$ is not supported. The association between feasibility testing and team performance is insignificant. In $\mathrm{H} 4$, we assume that team spirit leads to higher team performance. The association between team discourse and team performance is significantly positive $(\beta=0.22, \mathrm{p}<0.05)$; H4 was supported. In model 3, we tested the interaction effect of task discourse and team spirit on team performance. The interaction effect is significantly negative $(\beta=-0.14, \mathrm{p}<0.05)$; H5 is supported. 
Table 3 Standardizes coefficients (Est.) and standard errors (S.E.) from structural equation modeling with robust ML-estimator ${ }^{\text {i ii, iii }}$

\begin{tabular}{|c|c|c|c|c|c|c|c|c|c|c|c|c|c|c|}
\hline & Model 1 & & \multicolumn{6}{|c|}{ Model 2} & \multicolumn{6}{|c|}{ Model 3} \\
\hline & \multicolumn{2}{|l|}{$\begin{array}{c}\text { Team } \\
\text { performance }\end{array}$} & \multicolumn{2}{|c|}{$\begin{array}{c}\text { Task } \\
\text { discourse }\end{array}$} & \multicolumn{4}{|c|}{$\begin{array}{c}\text { Team } \\
\text { performance }\end{array}$} & \multicolumn{3}{|c|}{$\begin{array}{c}\text { Task } \\
\text { discourse }\end{array}$} & \multicolumn{3}{|c|}{$\begin{array}{c}\text { Team } \\
\text { performance }\end{array}$} \\
\hline & Est. $\mathrm{SE}$ & $p$ & Est. & SE & $p$ & Est. & SE & $p$ & Est. & $\mathrm{SE}$ & $p$ & Est. & SE & $p$ \\
\hline R\&D intensity & $-0.04(0.07)$ & & & & & -0.03 & $(0.05)$ & & & & & -0.03 & $(0.06)$ & \\
\hline Task type & $0.04(0.06)$ & & & & & -0.01 & $(0.06)$ & & & & & -0.01 & $(0.06)$ & \\
\hline Task novelty & $-0.04(0.07)$ & & & & & -0.12 & $(0.06)$ & * & & & & -0.10 & $(0.06)$ & $*$ \\
\hline Team size & $0.10(0.07)$ & & & & & 0.15 & $(0.06)$ & $* *$ & & & & 0.15 & $(0.07)$ & $* *$ \\
\hline Team creativity & & & 0.31 & $(0.10)$ & $* * *$ & -0.17 & $(0.08)$ & $* *$ & 0.32 & $(0.10)$ & $* * *$ & -0.17 & $(0.09)$ & $*$ \\
\hline Feasibility testing & & & 0.04 & $(0.09)$ & & 0.11 & $(0.09)$ & & 0.04 & $(0.10)$ & & 0.10 & $(0.09)$ & \\
\hline Task discourse (TD) & & & & & & 0.34 & $(0.10)$ & $* * *$ & & & & 0.3 & $(0.08)$ & $* * *$ \\
\hline Team spirit (TS) & & & & & & 0.22 & $(0.11)$ & & & & & 0.2 & $(0.09)$ & $* *$ \\
\hline $\mathrm{TD} \times \mathrm{TS}$ & & & & & & & & & & & & -0.14 & $(0.07)$ & $* *$ \\
\hline
\end{tabular}

${ }^{\mathrm{i}} \mathrm{N}=250$

${ }^{\text {ii }}$ Estimated coefficients are significant with p-values $\leq .10^{*}, \leq .05^{* *}$, and $\leq .01 * * *$

${ }^{i i i}$ Model-fit indices from model 2: $\mathrm{chi}^{2}(\mathrm{df})=222.67$ (136); RMSEA $=0.05 ; \mathrm{CFI}=0.96$; $\mathrm{SRMR}=$ 0.06

We plotted the interaction between task discourse and team spirit to obtain a clearer understanding of the interaction effect and its direction (see left in Fig 2). The labels low and high represent values of one standard deviation below and one standard deviation above the sample mean, respectively. The plot indicates that team spirit decreases the positive effect of task discourse on team performance in the case of high team spirit. To illustrate this more precisely, we calculated and draw the marginal effect of task discourse on team performance in dependency of team spirit; see right graph in Fig 2) (Brambor et al. 2006). The dotted lines in the right graph show the $95 \%$ confidence bounds of the marginal effect. The marginal effect and the confidence bounds indicate that the influence of task discourse does not only decrease. In the case of high team spirit, the confidence bounds are above and below the zero line indicating that the influence of task discourse on team performance becomes inconsistent and statistically insignificant (Berry et al. 2012; Brambor et al. 2006). 

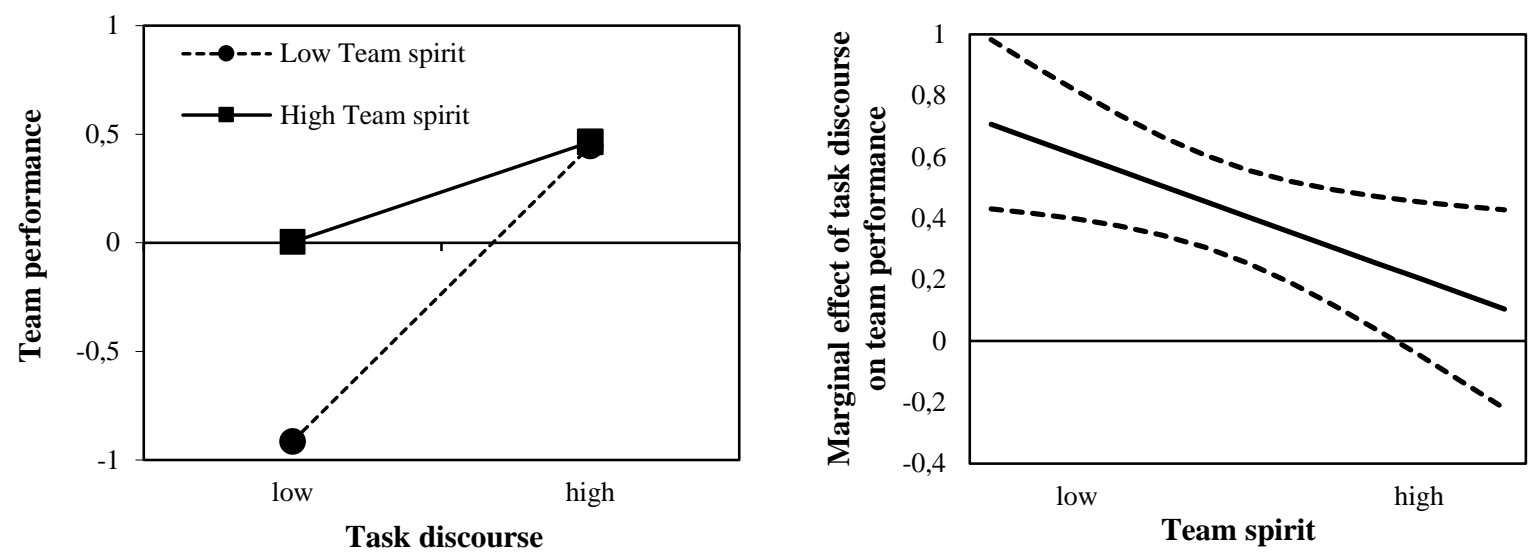

Fig 2 Team performance resulting from task discourse, team spirit, and their interaction (left) and the marginal effect of task discourse on team performance in dependence of team spirit (right).

\section{Discussion}

study contributes to research on sensemaking in team innovation processes (Brun 2016), as the results show the need for sensemaking through task discourse when firms aim to achieve benefits from team creativity. The total effect of creativity on team performance is insignificant, while the indirect effect of team creativity on team performance is significantly positive. This finding contributes to the debate on the relationship between creativity and innovation (Levitt 2002). Our results indicate that creativity does not automatically lead to innovation. Idea generation is not sufficient because team members need to bring ideas to work. Task discourse enables team members to challenge the innovation potential of ideas. Additionally, team members can refine their ideas through task discourse. Although researchers agree that ambiguity is a key phenomenon in innovation processes, opinions differ regarding the usefulness of ambiguity. Mainstream literature highlights the dark side of ambiguity, including misunderstanding and escalating conflicts that impede interaction and learning (Simonin 1999). Scholars argue that clarity, not ambiguity, should be favored in innovation processes. Other scholars emphasize that ambiguity provides the exploitation of multiple interpretations in creative problem solving (Brown and Eisenhardt 1995; Eisenberg 2007). By relating to the sensemaking approach (Weick 1995), we integrate both perspectives and enrich the research on innovation processes teams. We argue that team members' ability to cope with ambiguity decides the success of teamwork. Previous researchers have highlighted the importance of sensemaking for innovation (Huarng and Ribeiro-Soriano 2014) and the antecedents and outcomes of sensemaking within teams (Akgün et al. 2012; Akgün et al. 2006) but neglected the underlying sensemaking processes. Our study introduces task discourse as a valuable sensemaking mechanism in teams by moving the concept of task discourse from the alliance level (Pesch and Bouncken 2017a) to the team level. Our findings on task discourse might also enrich the increasing research on entrepreneurship (Markin et al. 2017) particularly in the context of collaborative 
entrepreneurship (Ribeiro-Soriano and Urbano 2009; Welbourne and Pardo-del-Val 2009). Task discourse might be a valuable mechanism for entrepreneurial opportunity discovery and creation.

The present study also extends the social cognition approach of innovation processes (Akgün et al. 2006). Social cognition researchers conceptualize aspects of human information processing specifically the role of the mental processes of people interacting with one another (Martin and Clark 1990). The social cognition approach highlights the importance of sensemaking for learning within innovation teams (Akgün et al. 2006). By considering the interplay of task discourse and team spirit, we address how the social context influences sensemaking within teams. These findings answer the call to elaborate advantages and disadvantages team spirit might bring to teams (Silva et al. 2014). These results indicate team spirit has ambivalent effects. Although team spirit enhances team performance, it decreases the beneficial effect of task discourse. Social factors, such as trust, familiarity, and proximity, enable team members to share information, but team spirit lowers an individual's willingness to challenge different perspectives to avoid tensions for the sake of unity. The finding about the dark side of team spirit relates to the insights into groupthink and social conformity (Janis 1972).

For practice, therefore, it is important to find the right balance of task discourse and team spirit. Although team spirit and task discourse have positive effects on team performance, team leaders and members should be aware of the dysfunctional interaction between task discourse and team spirit. These results also inform managers that task discourse can transform team creativity into innovation. Managers should be aware that being creative does not automatically lead to innovation. Beyond our empirical findings, firms should be aware of their employees' ability and willingness to enter into a discourse with other team members. Not every team member is willing and able to do this. Promoting task discourse is counterproductive in teams in which team members are unable or unwilling to enter into task discourse. Thus, firms need to recruit employees with high discourse ability and willingness, and then the firms can train employees to develop discourse abilities.

\subsection{Post Hoc Analysis}

As mentioned in the results section, we found a significant negative relationship between task novelty and team performance and a significantly positive relationship between team size and team performance when we added task discourse and team spirit in model 2 and model 3 (see Table 4). In two post hoc models, we examined whether these influences can be explained by relevant interactions of task novelty or team size with task discourse and team spirit. The three-way interaction effect of task novelty, task discourse, and team spirit on team performance is insignificant (see Table 4). 
Table 4 Post-Hoc-models for the 3-way interactions of task discourse and team spirit with task novelty respectively team size ${ }^{\text {i, ii iii }}$

\begin{tabular}{|c|c|c|c|c|c|c|c|c|}
\hline & \multicolumn{4}{|c|}{ Model 4} & \multicolumn{4}{|c|}{ Model 5} \\
\hline & \multicolumn{2}{|c|}{ Task discourse } & \multicolumn{2}{|c|}{ Team performance } & \multicolumn{2}{|c|}{ Task discourse } & \multicolumn{2}{|c|}{ Team performance } \\
\hline & $\begin{array}{ll}\text { Est. } & \text { SE }\end{array}$ & $p$ & Est. & $p$ & $\begin{array}{ll}\text { Est. } & \text { SE }\end{array}$ & $p$ & Est. & $p$ \\
\hline R\&D intensity & & & $-0.01(0.01)$ & & & & $-0.00(0.01)$ & \\
\hline Task type & & & $-0.01(0.08)$ & & & & $-0.02(0.08)$ & \\
\hline Task novelty (TNO) & & & $-0.19(0.13)$ & & & & $-0.20(0.12)$ & $*$ \\
\hline Team size (TSI) & & & $0.08(0.04)$ & $* *$ & & & $0.10(0.04)$ & $* *$ \\
\hline Team creativity & $0.24(0.09)$ & $* * *$ & $-0.15(0.09)$ & $*$ & $0.25(0.09)$ & $* * *$ & $-0.16(0.09)$ & $*$ \\
\hline Feasibility testing & $0.05(0.08)$ & & $0.11(0.09)$ & & $0.04(0.08)$ & & $0.13(0.10)$ & \\
\hline Task discourse (TD) & & & $0.37(0.08)$ & $* * *$ & & & $0.41(0.08)$ & $* * *$ \\
\hline Team Spirit (TS) & & & $0.30(0.12)$ & $* *$ & & & $0.21(0.10)$ & $* *$ \\
\hline $\mathrm{TD} \times \mathrm{TS}$ & & & $-0.24(0.10)$ & $* *$ & & & & \\
\hline $\mathrm{TD} \times \mathrm{TNO}$ & & & $0.04(0.15)$ & & & & & \\
\hline $\mathrm{TS} \times \mathrm{TNO}$ & & & $0.33(0.21)$ & & & & & \\
\hline $\mathrm{TD} \times \mathrm{TS} \times \mathrm{TNO}$ & & & $0.02(0.18)$ & & & & & \\
\hline $\mathrm{TD} \times \mathrm{TS}$ & & & & & & & $-0.19(0.09)$ & $* *$ \\
\hline $\mathrm{TD} \times \mathrm{TSI}$ & & & & & & & $0.09(0.04)$ & $* *$ \\
\hline $\mathrm{TS} \times \mathrm{TSI}$ & & & & & & & $-0.09(0.05)$ & $*$ \\
\hline $\mathrm{TD} \times \mathrm{TS} \times \mathrm{TSI}$ & & & & & & & $-0.09(0.05)$ & $*$ \\
\hline
\end{tabular}

${ }^{\mathrm{i}}$ Results show unstandardized coefficients (Est.) and standard errors (S.E.) from robust ML-estimator ${ }^{\text {ii }} \mathrm{N}=250$

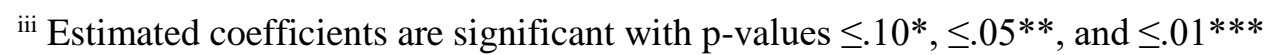

The interaction model for team size, however, provides a deeper understanding of the ambivalent effects of team spirit on team performance. The estimated coefficients of the two-way interactions (team size with task discourse and team size with team spirit) and the three-way interaction (team size with task discourse and team spirit) are significant. To develop a better understanding of the significant threeway-interaction effect, we draw Figure 3. First, this figure indicates that higher task discourse is beneficial for all four constellations. Second, the beneficial effect of team spirit depends on team size. Team performance do not differ between low vs. large team size when both team spirit and task discourse are low. With low team spirit and high task discourse the team performance only shows an average level in small teams, while large teams achieve highest team performance. Thus, team size shapes the negative interplay of task discourse and team spirit. 


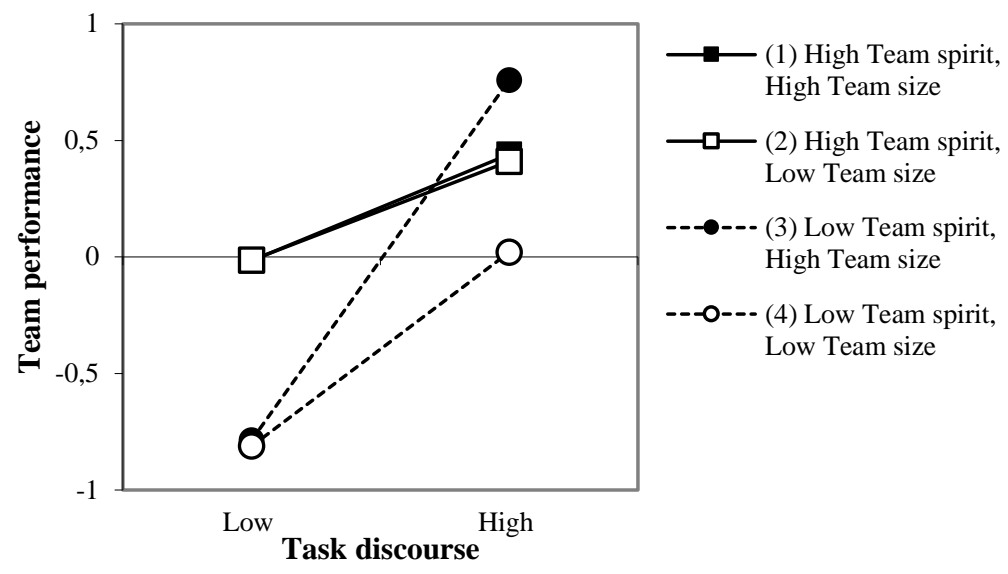

Fig 3 Team performance resulting from task discourse, team spirit, team size, and their interactions

\subsection{Limitations and Avenues for Future Research}

When interpreting the results of this study, we must point out several limitations. Generalizing the results is difficult because the sample consists of firms in the German manufacturing industry. This sample might be limited in generalizability because team processes and willingness to perform task discourse might differ among cultures and industries. Our study also concentrates on team creativity and testing of ideas and solutions as sources of task discourse. Team members' characteristics and diversity or team norms might be further important antecedents of sensemaking through task discourse. In virtual teams, where team members are dispersed around the world (Montoya-Weiss et al. 2001), infrastructure and communication media might also shape task discourse. Future research should consider these different contextual factors of task discourse.

Another interesting question might be how team members can avoid the limiting effect of team spirit on task discourse. An important factor might be the establishment of team norms, which prevent over-hasty consensus findings and motivate team members to challenge each other's perspective. These norms should also include how to cope with dissent constructively and task-oriented. Otherwise, challenging each other's perspective can trigger a dysfunctional conflict spiral that transforms from the task to the personal level (Mooney et al. 2007), destroying team spirit. This study concentrates on sensemaking through communication. Sensemaking scholars highlight that formalization can be an additional means of making sense (Vlaar et al. 2006; Weick 1995), as formalization can support team members' information processing and coping with innovation teams' inherent ambiguity (Brown 2000). However, formalization involves the danger of inhibiting flexibility and creativity by promoting mindless or rigid adherence to documented and codified processes (Mintzberg 1994). Thus, the question arises whether formalization and which kind of formalization can improve sensemaking and innovation in teams. 


\section{References}

Açıkgöz A, Günsel A, Kuzey C, Zaim H (2016) Team foresight in new product development projects. Group Decis Negot 25:289-323

Akgün AE, Keskin H, Lynn G, Dogan D (2012) Antecedents and consequences of team sensemaking capability in product development projects. R\&D Management 42:473-493

Akgün AE, Lynn GS, Y1lmaz C (2006) Learning process in new product development teams and effects on product success: A socio-cognitive perspective. Ind Market Manag 35:210-224

Amabile TM (1996) Creativity in Context. Westview Press, Boulder, CO

Angelsberger M, Kraus S, Mas-Tur A, Roig-Tierno N (2017) International opportunity recognition: An overview. Journal of Small Business Strategy 27:19-36

Ashmos DP, Nathan ML (2002) Team sense-making: A mental model for navigating uncharted territories. Journal of Managerial Issues 14:198-217

Baarup A, Breunig M, Dufour M, Gehrig J, Geldmacher F, Heberger M, Repenning J (2015) Industry 4.0 - How to navigate digitalization of the manufacturing sector.

Bacon DR, Sauer PL, Young M (1995) Composite reliability in structural equations modeling. Educ Psychol Meas 55:394-406

Bagozzi RP, Yi Y (1988) On the evaluation of strucutral equation models. Journal of Academy of Marketing Science 16:74-94

Bain PG, Mann L, Pirola-Merlo A (2001) The innovation imperative: The relationships between team climate, innovation, and performance in research and development teams. Small Gr Res 32:5573

Barczak G, Lassk F, Mulki J (2010) Antecedents of team creativity: An examination of team emotional intelligence, team trust and collaborative culture. Creat Innov Manag 19:332-345

Berry WD, Golder M, Milton D (2012) Improving Tests of Theories Positing Interaction. J Polit 74:653-671

Bollen KA, Hoyle RH (1990) Perceived Cohesion: A Conceptual and Empirical Examination. Soc Forces 69:479-504

Bouncken R, Brem A, Kraus S (2016a) Mutli-cultural teams as sources for creativity and innovation: The role of cultural diverstiy on team performance. International Journal of Innovation Management 20:1650012

Bouncken RB, Kraus S (2013) Innovation in knowledge-intensive industries: The double-edged sword of coopetition. J Bus Res 66:2060-2070

Bouncken RB, Pesch R, Reuschl A (2016b) Copoiesis: Mutual knowledge creation in alliances. Journal of Innovation \& Knowledge 1:44-50

Boyt T, Lusch R, Mejza M (2005) Theoretical models of the antecedents and consequences of organizational, workgroup, and professional esprit de corps. Eur Manag J 23:682-701 
Brambor T, Clark WR, Golder M (2006) Understanding interaction models: Improving empirical analyses. Polit Anal:63-82

Brown AD (2000) Making sense of inquiry sensemaking. J Manage Stud 37

Brown SL, Eisenhardt KM (1995) Product development: Past research, present findings, and future directions. Acad Manage Rev 20:343-378

Brun EC (2016) Ambidexterity and ambiguity: The link between ambiguity management and contextual ambidexterity in innovation. International Journal of Innovation and Technology Management 13:1650013

Burningham C, West MA (1995) Individual, climate, and group interaction processes as predictors of work team innovation. Small Gr Res 26:106-117

Cabrales A, Calvó-Armengol A (2007) Corporate downsizing to rebuild team spirit: How costly voting can foster cooperation. J Eur Eccon Assoc 5:1016-1042

Calantone RJ, Di Benedetto CA, Meloche MS (1988) Strategies of product and process innovation: A loglinear analysis. R\&D Management 18:13-21

Camelo-Ordaz C, García-Cruz J, Sousa-Ginel E (2015) The influence of top management team conflict on firm innovativeness. Group Decis Negot 24:957-980

Chen M-H (2006) Understanding the Benefits and Detriments of Conflict on Team Creativity Process. Creat Innov Manag 15:105-116

Cho E, Kim S (2015) Cronbach's coefficient alpha: Well known but poorly understood. Organ Res Methods 18:207-230

Christiansen JK, Varnes CJ (2009) Formal rules in product development: Sensemaking of structured approaches. J Prod Innovat Manag 26:502-519

Cooper RG, Edgett SJ, Kleinschmidt EJ (1999) New product portfolio management: Practices and performance. J Prod Innovat Manag 16:333-351

De Dreu CKW, Gelfand MJ (2008) Conflict in the workplace: Sources, functions, and dynamics across multiple levels of analysis. In: De Dreu CKW, Gelfand MJ (eds) The Psychology of Conflict and Conflict Management in Organizations. Taylor \& Francis Group, London u.a., pp $3-54$

Dougherty D (1992) Interpretive barriers to successful product innovation in large firms. Organ Sci 3:179-202

Dougherty D, Borrelli L, Munir K, O’Sullivan A (2000) Systems of organizational sensemaking for sustained product innovation. J Eng Technol Manage 17:321-355

Eisenberg EM (2007) Strategic Ambiguities. Sage, Thousands Oaks

Elsbach KD, Hargadon AB (2006) Enhancing creativity through "mindless" work: A framework of workday design. Organ Sci 17:470-483

Fornell C, Larcker DF (1981) Evaluating structural equation models with unobservable variables and measurement error. J Marketing Res 18:39-50 
Giordano R, Brugnach M, Pluchinotta I (2017) Ambiguity in problem framing as a barrier to collective actions: Some hints from groundwater protection policy in the Apulia region. Group Decis Negot 26:911-932

Girotra K, Terwiesch C, Ulrich KT (2010) Idea generation and the quality of the best idea. Manage Sci 56:591-605

Guzzo RA, Shea GP (1992) Group performance and intergroup relations in organizations. In: Dunette MD, Hough LM (eds) Handbook of industrial and organizational psychology, vol 3.2 edn. Consulting Psychologist Press, Palo Alto, pp 199-267

Habermann H, Schulte R (2017) Analyzing non-linear dynamics of organic growth: Evidence from small German new ventures. Journal of Small Business Strategy 27:36-64

Hackman JR (2012) From causes to conditions in group research. J Organ Behav 33:428-444

Hackman JR, Morris CG (1983) Group tasks, group interaction, and group performance effectiveness. In: Blumberg HH, Hare AP, Kent V, Davies M (eds) Small groups and social interaction, vol 1. Wiley \& Sons, Chichester, UK,

Hair JF, Black B, Babin B, Anderson RE, Tatham RL (2010) Multivariate data analysis. 7 edn. Pearson Prentice Hall, Upper Saddle River, NJ

Hoegl M, Gemuenden HG (2001) Teamwork quality and the success of innovative projects: A theoretical concept and empirical evidence. Organ Sci 12:435-449

Hu Lt, Bentler PM (1999) Cutoff criteria for fit indexes in covariance structure analysis: Conventional criteria versus new alternatives. Structural Equation Modeling: A Multidisciplinary Journal 6:1-55

Huarng K-H, Ribeiro-Soriano DE (2014) Developmental management: Theories, methods, and applications in entrepreneurship, innovation, and sensemaking. J Bus Res 67:657-662

Im S, Montoya MM, Workman JP (2013) Antecedents and consequences of creativity in product innovation teams antecedents and consequences of creativity in product innovation teams. $\mathrm{J}$ Prod Innovat Manag 30:170-185

Janis IL (1972) Victims of groupthink; a psychological study of foreign-policy decisions and fiascoes. Houghton Mifflin, Boston

Jaworski BJ, Kohli AK (1993) Market orientation: Antecedents and consequences. J Marketing 57:5370

Jia L, Shaw JD, Tsui AS, Park T-Y (2014) A social-structural perspective on employee-organization relationships and team creativity. Acad Manage J 57:869-891

Klein A, Moosbrugger H (2000) Maximum likelihood estimation of latent interaction effects with the LMS method. Psychometrika 65:457-474

Kratzer J, Leenders RTAJ, van Engelen JML (2004) Stimulating the potential: Creative performance and communication in innovation teams. Creat Innov Manag 13:63-71 
Leenders RTAJ, Van Engelen JML, Kratzer J (2007) Systematic design methods and the creative performance of new product teams: Do they contradict or complement each other? J Prod Innovat Manag 24:166-179

Levitt T (2002) Creativity is not enough. Harvard Bus Rev 80:137-145

Li J, Hambrick DC (2005) Factional groups: A new vantage on demographic faultlines, conflict, and disintegration in work teams. Acad Manage J 48:794-813

Lovelace K, Shapiro DL, Weingart LR (2001) Maximizing cross-functional new product teams' innovativeness and constraint adherence: A conflict communications perspective. Acad Manage J 44:779-793

Maitlis S, Christianson M (2014) Sensemaking in organizations: Taking stock and moving forward. Acad Manag Ann 8:57-125

Markin E, Swab RG, Marshall DR (2017) Who is driving the bus? An analysis of author and institution contributions to entrepreneurship research. Journal of Innovation \& Knowledge 2:19

Martin LL, Clark LF (1990) Social cognition: Exploring the mental processes involved in human and social interaction. In: Eysenck MW (ed) Cognitive psychology: An international review. Wiley, Hillsdale, pp 195-216

Mintzberg H (1994) The rise and fall of strategic planning. Prentice Hall, Hemel Hempstead

Miron-Spektor E, Erez M, Naveh E (2011) The effect of conformist and attentive-to-detail members on team innovation: Reconciling the innovation paradox. Acad Manage J 54:740-760

Mohammed S, Ringseis E (2001) Cognitive diversity and consensus in group decision making: The role of inputs, processes, and outcomes. Organ Behav Hum Dec 85:310-335

Montoya-Weiss MM, Massey AP, Song M (2001) Getting It Together: Temporal coordination and conflict management in global virtual teams. Acad Manage J 44:1251-1262

Mooney AC, Holahan PJ, Amason AC (2007) Don't take it personally: Exploring cognitive conflict as a mediator of affective conflict. J Manage Stud 44:733-758

Muthén LK, Muthén BO (1998-2012) Mplus User's Guide. 7th edn. Muthén \& Muthén, Los Angeles CA

Olugbola SA (2017) Exploring entrepreneurial readiness of youth and startup success components: Entrepreneurship training as a moderator. Journal of Innovation \& Knowledge 2:155-171

Oppl S (2017) Supporting the collaborative construction of a shared understanding about work with a guided conceptual modeling technique. Group Decis Negot 26:247-283

Pesch R, Bouncken RB (2017a) The double-edged sword of cultural distance in international alliances - how perceived cultural distance influences trust and task discourse to drive new product development performance. Cross Cult Strateg M 24:33 - 54

Pesch R, Bouncken RB (2017b) How to achieve benefits from diverstiy in international alliances: Mechanisms and cultural intelligence. Glob Strateg J 
Pesch R, Bouncken RB, Kraus S (2015) Effects of communication style and age diversity in innovation teams. International Journal of Innovation and Technology Management $12: 1550029$

Phillips N, Lawrence TB, Hardy C (2004) Discourse and institutions. Acad Manage Rev 29:635-652

Pich MT, Loch CH, Meyer AD (2002) On uncertainty, ambiguity, and complexity in project management. Manage Sci 48:1008-1023

Postmes T, Spears R, Cihangir S (2001) Quality of decision making and group norms. J Pers Soc Psychol 80:918-930

Ribeiro-Soriano D, Urbano D (2009) Overview of collaborative entrepreneurship: An integrated approach between business decisions and negotiations. Group Decis Negot 18:419-430

Salojärvi H, Saarenketo S (2013) The effect of teams on customer knowledge processing, esprit de corps and account performance in international key account management. Eur J Marketing 47:987-1005

Silva T, Cunha MPe, Clegg SR, Neves P, Rego A, Rodrigues RA (2014) Smells like team spirit: Opening a paradoxical black box. Human Relations 67:287-310

Simonin BL (1999) Ambiguity and the process of knowledge transfer in strategic alliances. Strateg Manage J 20:595-623

Sivunen A (2006) Strengthening identification with the team in virtual teams: The leaders' perspective. Group Decis Negot 15:345-366

Slevin DP, Boone LW, Russo EM, Allen RS (1998) CONFIDE: A collective decision-making procedure using confidence estimates of individual judgements. Group Decis Negot 7:179-194

Smith HJ, Thompson R, Iacovou C (2009) The impact of ethical climate on project status misreporting. J Bus Ethics 90:577

Stasser G (1992) Information salience and the discovery of hidden profiles by decision-making groups: A "thought experiment”. Organ Behav Hum Dec 52:156-181

Stasser G (1999) The uncertain role of unshared information in collective choice. In: L. L. Thompson JML, \& D. M. Messick (ed) Shared cognition in organizations: The management of knowledge. Lawrence Erlbaum Associates, Hildsdale, pp 49-69

Stasser G, Titus W (1985) Pooling of unshared information in group decision making: Biased information sampling during discussion. J Pers Soc Psychol 48:1467-1478

Statistisches Bundesamt (2014) Bruttoinlands-Produkt 2013 für Deutschland: Begleitmaterial zur Pressekonferenz am 15. Januar 2014 in Berlin. Statistisches Bundesamt, Wiesbaden

Stewart GL, Barrick MR (2000) Team structure and performance: Assessing the mediating role of intrateam process and the moderating role of task type. Acad Manage J 43:135-148

Tjosvold D, Wong ASH, Feng Chen NY (2014) Constructively managing conflicts in organizations. Annu Rev Organ Psych 1:545-568 
Tsai M-H, Bendersky C (2016) The pursuit of information sharing: Expressing task conflicts as debates vs. disagreements increases perceived receptivity to dissenting opinions in groups. Organ Sci 27:141-156

van Knippenberg D, Schippers MC (2007) Work Group Diversity. Annu Rev Psyhcol 58:515-541 Vlaar PWL, van den Bosch FAJ, Volberda HW (2006) Coping with problems of understanding in interorganizational relationships: Using formalization as a means to make sense. Organ Stud 27:1617-1638

Weick KE (1995) Sensemaking in organizations. Sage Publications, Thousand Oaks

Weick KE (2005) Managing the unexpected: Complexity as distributed sensemaking. In: McDaniel RR, Drie DJ (eds) Uncertainty and surprise in complex systems: Questions on working with the unexpected. Springer, Berlin, pp 51-65

Welbourne TM, Pardo-del-Val M (2009) Relational capital: Strategic advantage for small and medium-size enterprises (SMEs) through negotiation and collaboration. Group Decis Negot $18: 483-497$

Williams KY, O'Reilly CA (1998) Demography and diversity in organizations: A review of 40 years of research. Res Organ Behav 20:77-140

Wittenbaum GM (1998) Information sampling in decision-making groups: The impact of members' task-relevant status. Small Gr Res 29:57-84

Wittenbaum GM, Hollingshead AB, Botero IC (2004) From cooperative to motivated information sharing in groups: moving beyond the hidden profile paradigm. Commun Monogr 71:286-310

Wittenbaum GM, Stasser G (1996) Management of information in small groups. In: NyeIn JL, Brower AM (eds) What's social about social cognition? Research on socially shared cognition in small groups. Sage, Thousand Oaks, pp 3-28

Workman M, Kahnweiler W, Bommer W (2003) The effects of cognitive style and media richness on commitment to telework and virtual teams. J Vocat Behav 63:199-219

Wright CR, Manning MR, Farmer B, Gilbreath B (2000) Resourceful sensemaking in product development teams. Organ Stud 21:807

Ziegler R, Diehl M, Zijlstra G (2000) Idea production in nominal and virtual groups: Does computermediated communication improve group brainstorming? Group Process Interg 3:141-158 